\title{
Stratal OT and Underspecification: Evidence from Tundra Nenets
}

\author{
Peter Staroverov ${ }^{1}$ and Darya Kavitskaya ${ }^{2}$ \\ ${ }^{1}$ Universität Leipzig and ${ }^{2}$ University of California, Berkeley
}

\section{Introduction}

Tundra Nenets (TN) is a Uralic language spoken in a vast area in Northern Russia (Janhunen 1984, 1986; Nikolaeva 2014; Salminen 1997, 2012; Tereshchenko 1956, 1965). In this article, we concentrate on $\mathrm{TN}$ consonantal alternations, such as cluster simplification, place loss, lenition, and a variety of NC-effects. We show that these alternations combine transparent and opaque interactions within the same phrasal domain of application. These interactions are particularly challenging to Stratal OT (Kiparsky 2000; forthc.; Bermúdez-Otero 2011; forthc.), a cyclic phonological theory where all opaque interactions have to follow from differences in grammar between cycles. The TN data seem to require ordering of processes within the same post-lexical domain.

We propose a way of reconciling the TN data with Stratal OT. First, we assume abstract autosegmental representations, relying on underspecification and hierarchical organization of features. Second, we incorporate the proposal of McCarthy (2008) that consonant cluster simplification starts with place loss. Finally, we propose that apparent opaque deletion mappings can be reanalyzed as coalescence, within the correspondence theory of McCarthy and Prince (1995; 1999). Our analysis unifies TN consonant cluster alternations and assumes only one surface glottal stop.

\section{Data}

The system of complex consonantal alternations of TN is described and analyzed extensively by Janhunen (1986), and the analysis of consonants alternating with glottal stops forms an important part of virtually all descriptions of TN phonology. The vowel inventory of TN is given in (1). We use the IPA in our transcription in most cases, except we follow Salminen $(1997,1998 \mathrm{a}, 2012)$ in using the symbol ' ${ }^{\circ}$. Unlike Salminen (1997, et seq.), we transcribe the shorter $a$-like vowel as $[\Lambda]$ rather than [ə] since this seems to capture the pronunciation of the vowel more closely.

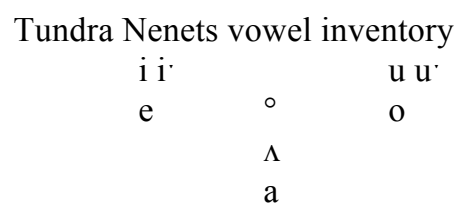

Salminen $(1997 ; 1998 \mathrm{a} ; 2012)$ describes the TN stress as alternating and falling on non-final odd syllables, causing the vowel $/ \mathrm{N} /$ to reduce to $\left[^{\circ}\right]$ in unstressed positions. This vowel may be pronounced as an over-short vowel, release of a consonant, or it may not be pronounced in some cases. The reduced vowel may be immediately adjacent to a full vowel, in which case the two vowels merge to form a long vowel, e.g. /mass/ [ma:?] 'place on chest under the outer layer of clothing'. Finally, the reduced vowel triggers a number of surface alternations such as postvocalic voicing.

The consonantal inventory of TN is presented in (2).

\footnotetext{
${ }^{*}$ We thank the audiences of GLOW 38 and AMP 2015 for their invaluable feedback. We are very grateful to our Tundra Nenets consultants for sharing their language with us. All errors and misinterpretations are of course our own.

(C) 2016 Peter Staroverov and Darya Kavitskaya

Proceedings of $A M P 2015$

Completed April 3, 2016
} 
Tundra Nenets consonantal inventory

\begin{tabular}{|l|c|c|c|c|c|}
\hline & labial & dental & palatal & velar & glottal \\
\hline stops & $\mathrm{p} \mathrm{p}^{\mathrm{j}} \mathrm{b} \mathrm{b}^{\mathrm{j}}$ & $\mathrm{t} \mathrm{t}^{\mathrm{j} ~ \mathrm{~d}^{\mathrm{j}}}$ & & $\mathrm{kg}$ & $?$ \\
\hline nasals & $\mathrm{m} \mathrm{m}^{\mathrm{j}}$ & $\mathrm{n} \mathrm{n}^{\mathrm{j}}$ & & $\mathrm{y}$ & \\
\hline fricatives & & $\mathrm{s} \mathrm{s}^{\mathrm{j}} \mathrm{z}^{\mathrm{j}}$ & & $\mathrm{x}$ & \\
\hline affricates & & $\mathrm{ts} \mathrm{ts}^{\mathrm{j}}$ & & & \\
\hline liquids & & $\mathrm{r}^{\mathrm{j}} 1 \mathrm{l}^{\mathrm{j}}$ & & & \\
\hline glides & $\mathrm{w} \mathrm{w}^{\mathrm{j}}$ & & $\mathrm{j}$ & & \\
\hline
\end{tabular}

All obstruents are voiced after nasals in TN. Furthermore, surface [z z $z^{j}$ only occur after nasals, and they do not contrast with $\left[\mathrm{ts} \mathrm{ts}^{\mathrm{j}}\right]$ or $\left[\mathrm{dz} \mathrm{dz}^{\mathrm{j}}\right]$ in this environment (Salminen 1997, 2012). Also, Salminen (2012) lists affricates $\mathrm{dz}$ and $\mathrm{dz}^{\mathrm{j}}$ (his $\mathrm{j}$ and $\mathrm{jy}$ ) in the consonant inventory of Western dialects, which do not seem to be a part of the inventory of the dialect spoken by our consultants.

\section{Consonant sandhi and glottal stop alternations}

All of the processes to be discussed here apply both within words and across word boundaries, and hence they are part of phrasal phonology.

The underlyingly voiceless obstruent stops $/ \mathrm{p}^{\mathrm{j}} \mathrm{t} \mathrm{t}^{\mathrm{j}} /$ surface as voiced $\left[\mathrm{b} \mathrm{b}^{\mathrm{j}} \mathrm{d}^{\mathrm{j}}\right.$ ] after a vowel. Voicing applies both within words, as in (3)a, and across word boundaries, as in (3)b. In the latter case the process is optional: in slow speech the two words do not form a phrase together, and no voicing applies across a phrasal boundary. As shown in (3)b phrasal voicing may be triggered both by full vowels, and by the reduced vowel $\left[{ }^{\circ}\right]$. These new data contradict the earlier findings of Kavitskaya and Staroverov (2010).

$$
\text { Postvocalic and postnasal voicing }
$$

$$
\begin{array}{lll}
\text { a. Word-medially } & \\
\text { /ja-ta/ } & \text { jada } & \text { 'earh-POSS.3SG' } \\
\text { /x } \Lambda \text { r } \Lambda \text {-ta/ } & \text { x } \Lambda \mathrm{r}^{\circ} \mathrm{da} & \text { 'knife-POSS.3SG'} \\
\text { cf. } / \text { jar-ta/ } & \text { jarta } & \text { 'side-POSS.3SG' }
\end{array}
$$

b. Across word boundaries (in connected speech)

$$
\begin{aligned}
& \text { /pedara } \operatorname{pas} \Lambda \operatorname{koj} \Lambda / \quad \quad \text { pedara } \operatorname{bas}^{\circ} \mathrm{koj}^{\circ} \\
& \text { forest beautiful 'the forest is beautiful' }
\end{aligned}
$$

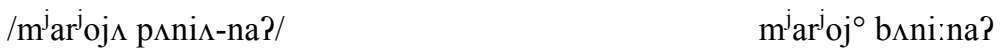

$$
\begin{aligned}
& \text { bald garment-POSS.PL1PL 'our bald garments' } \\
& / \mathrm{n}^{\mathrm{j}} \mathrm{k} \mathrm{k} \Lambda \mathrm{r}^{\mathrm{j}} \mathrm{o} \text { tara } / \quad \quad \mathrm{n}^{\mathrm{j}} \Lambda \mathrm{k}^{\circ} \mathrm{r}^{\mathrm{j}} \mathrm{o} \text { dara: } \\
& \text { prepare need.3SG 'it is necessary to get ready' }
\end{aligned}
$$

Phrase-finally /t d s n $\mathrm{y} /$ undergo place loss or debuccalization, yielding a glottal stop. This is illustrated in (4) where $/ \mathrm{N} /$ stands for an underlying nasal, which assimilates in place to the following consonant.

$$
\begin{aligned}
& \text { Phrase-final place loss } \\
& / \mathrm{m}^{\mathrm{j}} \text { at/ 'tent' } \\
& \text { cf. } / \mathrm{m}^{\mathrm{j}} \text { at- } \Lambda \mathrm{m} \text { ?/ 'tent-ACC.SG' } \\
& \mathrm{m}^{\mathrm{j}} \mathrm{a} \text { ? } \\
& \mathrm{m}^{\mathrm{j}} \mathrm{ad}^{\circ} \mathrm{m} \text { ? } \\
& \text { /ma s / 'place on chest under the outer layer of clothing' } \\
& \text { cf. } / \mathrm{ma} \Lambda \mathrm{s}-\Lambda \mathrm{N} / \\
& \text { 'place on chest under the outer layer of clothing-GEN.SG' }
\end{aligned}
$$




\author{
$/ \mathrm{s}$ i'n/ 'lid' \\ $\mathrm{s}_{\mathrm{i}}^{\mathrm{j}}$ ? \\ cf. $/ \mathrm{s}^{\mathrm{j}} \mathrm{i}$ 'n-ta/ 'lid-POSS.3SG' $\quad \mathrm{s}^{\mathrm{j}} \mathrm{i}$ 'nda \\ /wi'y/ 'tundra' wi'? \\ cf. 'tundra-ACC.PL' wi'no
}

When the debuccalizing consonants are followed by a consonant, they trigger a number of additional alternations on the following segment. These alternations apply both within words and across word boundaries, and they exhibit a number of opaque interactions, challenging both Classical OT and Stratal OT analyses. The obstruents $/ \mathrm{t} \mathrm{s} /$ debuccalize before a sonorant, trigger hardening of a following fricative (i.e. $/ \mathrm{x} /$ to $[\mathrm{k}]$ and $/ \mathrm{s} \mathrm{s}^{\mathrm{j}} /$ to $\left[\mathrm{ts} \mathrm{ts}^{\mathrm{j}}\right]$ ), and inhibit postvocalic voicing on a following stop (5).

(5) Word-medial obstruents: debuccalization, deletion, and voicing inhibition

a. Word-medially

$/ \mathrm{m}^{\mathrm{j}} \mathrm{at}-1 \Lambda /$ 'tent-poss.2sG'

$\mathrm{m}^{\mathrm{j}} \mathrm{a} \mathrm{1}^{\circ}$

$/ \mathrm{m}^{\mathrm{j}}$ at-ta/ 'tent-POSS.3SG'

$\mathrm{m}^{\mathrm{j}}$ ata, ${ }^{*} \mathrm{~m}^{\mathrm{j}} \mathrm{ada}$

/jas-Xına/ 'piece of hair-LOC.SG'

$\mathrm{jak}^{\circ}$ na

/mass-xuna/

ma:kına

'place on chest under the outer layer of clothing-LOC.SG'

$/ \mathrm{S} \Lambda \mathrm{S}-\mathrm{S}^{\mathrm{j}} \Lambda /$ 'be strong-MOD.GER'

$\mathrm{s} \Lambda \mathrm{ts}^{\mathrm{j} \circ}$

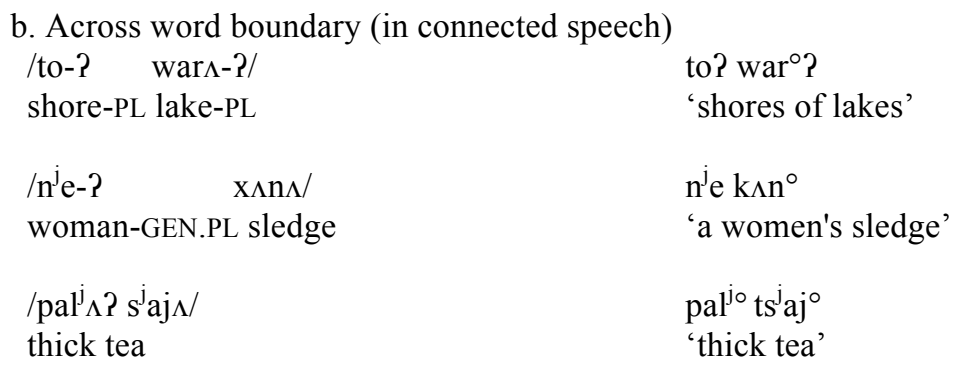

The cluster simplification processes in (5) counterfeed prevocalic voicing, resulting in a chain shift pattern whereby, for instance, underlying / VtV/ changes to [VdV] but underlying /VstV/ surfaces as [VtV]. On the other hand, cluster simplification counterbleeds consonant strengthening: the first consonant of the sequence does not surface in $/ \mathrm{n}^{\mathrm{j}} \mathrm{e}$ ? $\mathrm{x} \Lambda \mathrm{n} \Lambda /\left[\mathrm{n}^{\mathrm{j}} \mathrm{e} \mathrm{k} \Lambda \mathrm{n}^{\circ}\right.$ ] 'a women's sledge', and there is apparently no surface reason for the first consonant of the second word to strengthen.

Unlike the pre-consonantal obstruents, nasals $/ \mathrm{n} \mathrm{y} /$ delete before sonorants. The behavior of nasals in front of [j] in the studied dialect may require further investigation (according to Salminen (1997; 2012), the nasals are preserved in this environment merging as [n]), and we leave this issue for future investigation. In front of obstruents, the nasals undergo place assimilation and trigger voicing and strengthening of a following consonant. We will loosely refer to these processes as NC effects (Herbert 1986; Steriade 1993; Padgett 1994; Pater 1999; Halpert 2012 a.o.).

(6) Word-medial nasals: deletion, place assimilation, voicing, and strengthening

a. Within words

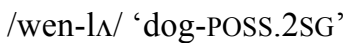

$/ \mathrm{s}^{\mathrm{j}} \mathrm{al} \Lambda \mathrm{n}-\mathrm{x} \Lambda \mathrm{nta} /$ 'underarm-POSS.3SG.DAT'

$/ \mathrm{s}^{\mathrm{j}} \mathrm{i} \cdot \mathrm{n}$-ta/ 'lid-POSS.3SG'

/pen-s ${ }^{\mathrm{j}} \Lambda /$ 'put-GER.MOD’

b. Across word boundaries (in connected speech)

/to-N wars/ 'lake-gen.sg shore'

$/ n^{\mathrm{j}} \mathrm{e}-\mathrm{N}$ x $\wedge$ n/ 'woman-GEN.SG sledge' $\mathrm{wel}^{\circ}$

$\mathrm{s}^{\mathrm{j}} \mathrm{al}^{\circ} \mathrm{ng} \mathrm{gnda}$

$\mathrm{s}^{\mathrm{j}} \mathrm{i}$ nda

penz ${ }^{\mathrm{j} \circ}$

to war $^{\circ}$

$\mathrm{n}^{\mathrm{j}}$ en $\mathrm{g}_{\Lambda} \mathrm{n}^{\circ}$ 
To summarize, the underlying / $\mathrm{d}$ s $\mathrm{n} \mathrm{y} /$ show up unchanged only word-initially. Intervocalically, the underlying / $/$ / is voiced to [d], whereas phrase-finally all consonants neutralize to a glottal stop. The fate of word- and phrase-medial consonant clusters depends on the quality of both consonants, as shown in (7).

\begin{tabular}{|c|c|c|c|}
\hline $\mathrm{C}_{1}$ & $\mathrm{C}_{2}$ & Output & Processes \\
\hline$/ \mathrm{t} \mathrm{d} \mathrm{s} /$ & $/ \mathrm{p}^{\mathrm{j}} \mathrm{t} \mathrm{t}^{\mathrm{j}} /$ & {$\left[p p^{j} t t^{j}\right]$} & Cluster simplification, no postvocalic voicing \\
\hline$/ \mathrm{t} \mathrm{d} \mathrm{s} /$ & $/ \mathrm{s} \mathrm{s}^{\mathrm{j}} \mathrm{x} /$ & {$\left[\right.$ ts ts $\left.^{j} \mathrm{k}\right]$} & Cluster simplification, strengthening \\
\hline$/ \mathrm{t} \mathrm{d} \mathrm{s/}$ & $/ \mathrm{mnn} 1 \mathrm{wj} /$ & $\mathrm{P}+\mathrm{C}_{2}$ & Debuccalization \\
\hline$/ \mathrm{n} \mathrm{y} /$ & $/ \mathrm{mnn} 1 \mathrm{w}(\mathrm{j}) /$ & $\mathrm{C}_{2}$ & Cluster simplification \\
\hline$/ \mathrm{n} \mathrm{y} /$ & $/ p p^{j} t^{j} x /$ & $\mathrm{ND}$ & Place assimilation, NC-effects \\
\hline$/ \mathrm{n} \mathrm{y} /$ & $/ \mathrm{s} \mathrm{s}^{\mathrm{j}} /$ & {$\left[\mathrm{nz} \mathrm{nz}^{\mathrm{j}}\right]$} & Place assimilation, postnasal voicing \\
\hline
\end{tabular}

As we will see below, the analysis of these alternations in OT or in Stratal OT presents a significant challenge. On the one hand, several processes interact opaquely or lead to chain shifts. On the other hand however, all of these processes seem to occur at the same level (post-lexical), since they all occur across word boundaries, and there are no fine-grained phrasing distinctions where one process would apply and another one would not. We illustrate this problem in Section 4 and propose a solution in Section 5.

\section{The problems}

TN consonant sandhi processes present two problems for an OT analysis, which we will illustrate in turn. The process of fricative strengthening, illustrated by the examples in (5) and (6), can roughly be stated as follows (to be revised): $/ \mathrm{s} \mathrm{s}^{\mathrm{j}} \mathrm{x} / \rightarrow\left[\mathrm{ts} \mathrm{ts}^{\mathrm{j}} \mathrm{k}\right] / \mathrm{C}_{\text {_ }}$. This strengthening process is rendered opaque by cluster simplification since the obstruents $/ \mathrm{t} \mathrm{s} /$ are deleted before an obstruent. In other words, consonant cluster simplification removes underlying motivation for strengthening, representing a counterbleeding order. In order to derive the correct result for sequences of obstruents, the two processes have to be ordered as in (8). We assume that vowel reduction applies at the lexical level.

\section{Counterbleeding in Tundra Nenets consonant sandhi}

\begin{tabular}{|l|c|}
\hline Input & $\mathrm{n}^{\mathrm{j}} \mathrm{e}$ ? $\mathrm{\Lambda} \mathrm{n}^{\circ}$ \\
\hline Strengthening & $\mathrm{n}^{\mathrm{j}} \mathrm{e} ? \mathrm{k} \Lambda \mathrm{n}^{\circ}$ \\
\hline Cluster simplification & $\mathrm{n}^{\mathrm{j}} \mathrm{e} \mathrm{k} \Lambda \mathrm{n}^{\circ}$ \\
\hline Output & $\mathrm{n}^{\mathrm{j}} \mathrm{e} \mathrm{k} \Lambda \mathrm{n}^{\circ}$ \\
\hline & 'women's sledge' \\
\hline
\end{tabular}

The opaque interaction presented in (8) not only presents a problem for Classical OT (Prince \& Smolensky 2004) but also cannot be straightforwardly analyzed within Stratal OT (Kiparsky 2000; forthc.; Bermúdez-Otero forthc.). Stratal OT combines the basic tenets of OT with the assumption that certain morphosyntactic constituents define domains or cycles for phonological process application, and that the grammar (i.e. OT ranking) can be different at different cycles (see also McCarthy and Prince 1993). This latter assumption (i.e. cyclicity) originates in the work within the framework of Lexical Phonology (Kiparsky 1982; Kiparsky 1985; Mohanan 1986). One of the main predictions of Stratal OT is that the nonoutput-driven effects, such as opaque interactions, can all be accounted for by the differences in grammar between Strata or cycles (Bermúdez-Otero 2014).

The phrasal application of cluster simplification and strengthening presents a challenge for Stratal OT. In particular, both strengthening and cluster simplification illustrated in (8) apply across word boundaries in fast speech, and hence they are part of phrasal phonology, as evidenced by $/ \mathrm{n}^{\mathrm{j}} \mathrm{e}$ ? $\mathrm{x} \Lambda \mathrm{n} \Lambda /\left[\mathrm{n}^{\mathrm{j}} \mathrm{e} \mathrm{k} \Lambda \mathrm{n}^{\circ}\right]^{\text {' }} \mathrm{women}$ 's sledge' in (5). The opaque ordering of the two processes requires them to arise within two different strata, where say Stratum 1 (or S1) would have fricative strengthening but not cluster simplification while a larger domain Stratum 2 (S2) would simplify consonant clusters, but take the strengthened consonant as given. By assumption, S1 and S2 would be nested phrasal prosodic domains. However, such a theory inevitably predicts an unattested phrasing where cluster simplification applies but strengthening does not. Indeed, if two words in (8) were phrased as $\left[\left[\mathrm{n}^{\mathrm{j}} \mathrm{e}\right]_{\mathrm{S} 1}\left[\mathrm{x} \wedge \mathrm{n}^{\circ}\right]_{\mathrm{S} 1}\right]_{\mathrm{S} 2}$, then the boundary between the words would be a 
legitimate environment for cluster simplification (since this boundary is within the domain S2) but not for strengthening (since this boundary is not within S1).

This account would therefore predict a semi-casual speech style where $/ \mathrm{n}^{\mathrm{j}} \mathrm{e}$ ? $\mathrm{x} \Lambda \mathrm{n} \Lambda$ / 'women's sledge' would surface $*\left[\mathrm{n}^{\mathrm{j}} \mathrm{e} \mathrm{x} \Lambda \mathrm{n}^{\circ}\right]$ where the glottal stop is deleted, but strengthening does not occur. However, such a phrasing is impossible: strengthening and cluster simplification either both apply or both don't. In Section 5, we argue that the two processes can in fact be described as one mapping involving coalescence, rather than deletion plus assimilation. Such an analysis treats the seemingly opaque mapping in (8) as transparent, and therefore we can maintain that both processes belong to the same cycle.

A related problem for OT is posed by TN voicing alternations, which essentially involve a chain shift whereby underlying /VPtV/ maps to [VtV] (as shown in (5)) and underlying /VtV/ maps to [VdV] (as shown in (3)). Relying on the treatment of cluster simplification as coalescence, we propose that this chain shift can be analyzed as an instance of resistance to apply multiple input-output disparities at the same time. While voicing of input consonants is allowed in TN, changing both [voice] and [constricted glottis] in one mapping is not allowed. In Section 5, we propose to formalize this intuition in terms of constraint conjunction (Smolensky 1993), although a formalization within Harmonic Grammar is also possible.

\section{Analysis}

The proposed analysis provides a way of maintaining the basic assumptions of Stratal OT. We assume that the grammatical evaluation is entirely parallel at each cycle, but the grammar of TN contains multiple cycles or Strata with potentially different rankings. Specifically, we will appeal to two such strata: Lexical and Post-lexical. Additional motivation for the stratal view of TN phonology comes from the fact that there is a clear division between the processes that apply across word boundaries and those that only operate within words. Section 5.1 provides an overview of the proposed analysis. Section 5.2 introduces our constraint set. Sections 5.3 and 5.4 describe the grammar of TN lexical and post-lexical alternations, respectively.

5.1 An overview We analyze the glottal stop in TN as a placeless consonant, treating debuccalization formally as loss of the place features. While there is ample precedent for assuming that glottal stop is placeless (Bessell \& Czaykowska-Higgins 1992; Bessell 1993; McCarthy 1994; Rose 1996), we do not assume that this specification of laryngeals is universal (see Lombardi 2001; de Lacy 2006; McCarthy 2008). There may be independent evidence from TN supporting the analysis of the glottal stop as placeless. In particular, the central vowel $/ \Lambda /$ assimilates to a full vowel across a glottal stop, suggesting that place spreading may occur ignoring this consonant. However, the details of this process, and its potential application across $/ \mathrm{x} /$ remain to be further analyzed.

Our analysis of cluster simplification relies on the idea that reduction of consonant clusters has place loss as its precedent (McCarthy 2008). However, obstruents and nasals pattern differently with respect to debuccalization: while a placeless obstruent is essentially non-distinct from a glottal stop, a placeless nasal still differs from it in nasality (McCarthy 2008). The loss of place features happens relatively early, at the lexical level, and does not lead to complete neutralization of the obstruent-nasal contrast. The other relevant processes happen post-lexically.

We further propose to treat cluster simplification in $\mathrm{TN}$ as coalescence. On our account, a post-lexical mapping like $/ \mathrm{P}_{1} \mathrm{~s}_{2} / \rightarrow\left[\mathrm{ts}_{1,2}\right]$ involves correspondence between two input segments and one output segment. This analysis avoids postulating intermediate strata (and hence intermediate phrases) that do not exist in TN. Our approach to fricative strengthening crucially relies on the fact that the first consonant of a cluster comes out of the lexical level as a stop (due to debuccalization), giving rise to a [-continuant] value on the ultimate output post-lexically.

While placeless obstruents (i.e. glottal stops) may either survive intact or coalesce with a following consonant post-lexically, the options are different for a placeless nasal coming from lexical level. A placeless nasal may coalesce with a following segment to yield a prenasal affricate, or else be turned into a glottal stop by losing nasality.

5.2 Constraints This section introduces the OT constraints that we take to be responsible for the alternations in question. We assume that debuccalization is triggered by a constraint belonging to the family of coda conditions (Itô 1986; 1989; McCarthy 2008; Kavitskaya and Staroverov 2010 a.o.), 
specifically, the prohibition on consonantal place features in the coda (9).

CODACOND: Assign a violation for each consonant specified for place in a coda.

We further assume that place features are privative, and thus a change from an oral to a laryngeal obstruent violates MAX(place). Treating debuccalization as loss in complexity, and in particular place loss, allows us to unify the alternations of TN final nasals and obstruents. However, the exact nature of place features, and the faithfulness constraints protecting these features are subject to a number of opposing views (see Itô et al. 1995; Zoll 1996; Davis \& Shin 1999; Lombardi 2001; McCarthy 2008), and thus the analysis proposed here may not necessarily extend to every language with debuccalization.

Similarly, we do not propose to treat all features as privative. In the absence of positive evidence, we will treat other features as equipollent, and hence protected by IDENT constraints (McCarthy and Prince 1995; 1999). The IDENT constraints play a crucial role in our analysis since they dictate which features may or may not be compromised in coalescence.

We propose that TN phrasal consonant sandhi can all be analyzed as resulting from coalescence - a mapping where two input segments merge in one output segment. Such a mapping is penalized by the constraint UNIFORMITY (to be abbreviated as UNIF). Another relevant faithfulness constraint is the segmental MAX that prohibits the deletion of full segments. In places of potential ambiguity with $\operatorname{MAX}($ place) we will refer to this constraint as $\operatorname{MAX}(\mathrm{seg})$.

Finally, segmental merger in TN competes with place spreading. We assume that place spreading violates a special faithfulness constraint, namely *SPREAD(place), also known as DEP-association-line (Kirchner 1993). In what follows, this constraint will be abbreviated as simply *SPREAD.

(10) *SPREAD: Assign a violation for each pair of underlying X-slot and place node which are not connected by an association line s.t. their correspondents are connected by an association line.

Our analysis of TN consonant sandhi relies on several markedness constraints. Placeless obstruents and placeless nasals behave differently in $\mathrm{TN}$, and in fact in many languages. While a placeless glottal stop is allowed in TN, and in a variety of languages, the placeless nasals are rare (though see Ramsammy 2012 for a possible case). We assume that both placeless nasals and the glottal stop are targeted by specific markedness constraints: $* \mathrm{~N}$ in (11) and $*$ ? in (12). A constraint specifically prohibiting glottal stop is also proposed by Lobardi (2002), de Lacy (2006), Rubach (2000), and Staroverov (2014), among others.

$$
\begin{aligned}
& \text { *N: assign a violation for every [+nasal] consonant lacking place features } \\
& \text { *?: assign a violation for every [-nasal] consonant lacking place features }
\end{aligned}
$$

The nasal-consonant sequences in TN exhibit a variety of NC effects such as postnasal voicing and hardening. These effects will be analyzed in more detail in Section 5.4, where we propose that nasals form complex segments together with a following obstruent. The phonology of such sequences (or complex segments) is governed by two relatively well-documented preferences: postnasal obstruents tend to be voiced and [-continuant] (Clements 1987; Steriade 1993; Padgett 1994; Pater 1996; 1999; Gouskova, et al. 2011; Halpert 2012). We encode these requirements as separate constraints, formulated in (13) and (14). These constraints are intended to apply to both sequences of segments and complex segments.

*NT: assign a violation for every [+ nasal] root node followed by a voiceless obstruent root node *NF: assign a violation for every [+nasal] root node followed by a [+continuant] obstruent root node

Finally, TN has a process of postvocalic voicing that we assume is triggered by the constraint *VT in (15). For the data considered in this article, the process could as well be analyzed as intervocalic, although the full treatment of TN morphophonology requires reference to a broader set of environments (Janhunen 1986; Salminen 1997; 2012).

*VT: assign a violation for every voiceless obstruent that is preceded by a vowel

Having introduced the constraints, we now proceed to the analysis of the TN alternations. 
5.3 Lexical level Word-final consonants lose their place at the lexical level in TN. Crucially, place loss preserves the contrast between final nasals and obstruents.

The tableau in (16) illustrates the ranking conditions holding at the lexical level with the analysis of obstruent debuccalization in the word /mans/ 'place on chest under the outer layer of clothing' ('place' is abbreviated as ' $\mathrm{pl}$ '). Here and in what follows we abstract away from the alternations involving the TN reduced vowel $/ \Lambda /$. Post-vocalically (as in (16)), this vowel coalesces with a preceding vowel to yield a long segment.

(16) Lexical debuccalization of obstruents

\begin{tabular}{|rr|c|c|c|c|c|c|}
\hline & $\mathrm{m}^{\mathrm{j}} \mathrm{a} \Lambda \mathrm{s}$ & CODACOND & MAX(seg) & MAX(pl) & $* 2$ & ID(cont) & ID(cg) \\
\hline a. & $\mathrm{m}^{\mathrm{j}} \mathrm{a}:$ ? & & & 1 & 1 & 1 & 1 \\
\hline b. & $\mathrm{m}^{\mathrm{j}} \mathrm{a}: \mathrm{s}$ & $\mathrm{W} 1$ & & $\mathrm{~L}$ & $\mathrm{~L}$ & $\mathrm{~L}$ & $\mathrm{~L}$ \\
\hline c. & $\mathrm{m}^{\mathrm{j}} \mathrm{a}:$ & & $\mathrm{W} 1$ & $\mathrm{~L}$ & $\mathrm{~L}$ & $\mathrm{~L}$ & $\mathrm{~L}$ \\
\hline
\end{tabular}

Word-final place loss is accounted for by the high ranking of CODACOND. Since glottal stop is the only placeless consonant in TN, place loss also implies a change in continuancy and in the feature [constricted glottis] for the underlying word-final $/ \mathrm{s} /$. This change is crucial, since at the post-lexical level the [continuant] glottal stop triggers strengthening of a following consonant. Finally, since MAX(seg) dominates MAX(place), the prohibition on final place features results in the removal of place rather than segment deletion.

At the lexical level, the fate of word-final nasals is very similar to that of the final obstruents: they lose their place. However, final nasals preserve their nasality, remaining distinct from obstruents. This is illustrated in (17) for a nasal-final word / $\mathrm{s}^{\mathrm{j}} \mathrm{i} \cdot \mathrm{n} /$ 'lid'.

(17) Lexical debuccalization of nasals

\begin{tabular}{|c|c|c|c|c|c|}
\hline $\mathrm{s}_{\mathrm{j}}^{\mathrm{j} \cdot \mathrm{n}}$ & CODACOND & IDENT(nas) & MAX(seg) & $\operatorname{MAX}(\mathrm{pl})$ & $* \mathrm{~N}$ \\
\hline a. $\quad \mathrm{s}^{\mathrm{j}} \mathrm{i} \cdot \mathrm{N}$ & & & & 1 & 1 \\
\hline b. $\mathrm{s}_{\mathrm{i}}^{\mathrm{i}}$ ? & & W1 & & 1 & $\mathrm{~L}$ \\
\hline c. $\mathrm{s}_{\mathrm{i}} \mathrm{n}$ & W1 & & & $\mathrm{L}$ & $\mathrm{L}$ \\
\hline d. $\quad \mathrm{s}^{\mathrm{j}_{\mathrm{i}}}$ & & & W1 & $\mathrm{L}$ & $\mathrm{L}$ \\
\hline
\end{tabular}

At the output of the lexical level, $/ \mathrm{s}^{\mathrm{j}} \mathrm{i}^{\mathrm{n}} \mathrm{n} /$ shows up as $\left|\mathrm{s}^{\mathrm{j}} \mathrm{i}^{\mathrm{N}} \mathrm{N}\right|$, an intermediate form with a final placeless nasal. Here and below we use straight brackets to denote intermediate representations. The final segment has to preserve its nasality due to high ranking of IDENT(nas) and relatively low ranking of $* \mathrm{~N}$.

The account presented so far straightforwardly generalizes to the word-medial environment where

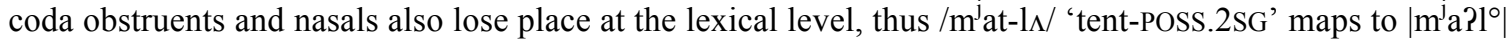

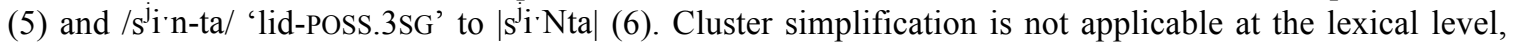
and this follows from the ranking of MAX and UNIFORMITY above *N and *?

5.4 Post-lexical level An important difference between lexical and post-lexical levels of the phonology of TN concerns their tolerance to placeless consonants. While placeless nasals and obstruents are freely allowed lexically, they are only tolerated in a restricted set of environments post-lexically. We assume that the constraints against placeless consonants $(* \mathrm{~N}, *$ ?) are high-ranked post-lexically, triggering cluster simplification. In this section, we present an account of fricative strengthening after obstruents.

Descriptively, the coda glottal stop (the output of lexical level) merges with following continuants to yield stops and affricates: $|\mathrm{P}+\mathrm{x}| \rightarrow[\mathrm{k}]$ and $\left|\mathrm{P}+\mathrm{s}, \mathrm{s}^{\mathrm{j}}\right| \rightarrow\left[\mathrm{ts}, \mathrm{ts}^{\mathrm{j}}\right]$ (5). We propose to analyze these mappings as coalescence. Two input segments, e.g. $\left|\mathrm{P}_{1} \mathrm{x}_{2}\right|$ correspond to one output segment $\left[\mathrm{k}_{1,2}\right]$, which preserves some properties of the first segment (continuancy) and some properties of the second one (place). This analysis relies on the assumption that coda $/ \mathrm{t} /$ and $/ \mathrm{s} /$ both come out from the lexical level as [-continuant].

The details of the coalescence analysis are spelled out in (18) for the phrase $\mid \mathrm{n}^{\mathrm{j}} \mathrm{e}$ $\mathrm{x} \wedge \mathrm{n}^{\circ} \mid\left[\mathrm{n}^{\mathrm{j}} \mathrm{e} k \wedge \mathrm{n}^{\circ}\right]$ 'women's sledge'. Here we analyze the consonant sandhi in connected speech, and hence it is assumed that the two words are phrased together (if they were not, the output would be $\left[\mathrm{n}^{\mathrm{j}} \mathrm{e}\right.$ ? $\left.\mathrm{x} \wedge \mathrm{n}^{\circ}\right]$ ). Indices show crucial instances of input-output correspondence. 
(18) Post-lexical glottal + obstruent coalescence in connected speech

\begin{tabular}{|rl|l|l|l|c:c|c|}
\hline & $\mathrm{n}^{\mathrm{j}} \mathrm{e}_{1} \mathrm{x}_{2} \Lambda \mathrm{n}^{\circ}$ & MAX & $* ?$ & *SPREAD & ID(cont) & ID(cg) & UNIF \\
\hline a. $\mathrm{n}^{\mathrm{j}} \mathrm{e} \mathrm{k}_{1,2} \Lambda \mathrm{n}^{\circ}$ & & & & 1 & 1 & 1 \\
\hline b. $\mathrm{n}^{\mathrm{j}} \mathrm{e}_{1} \mathrm{x}_{2} \Lambda \mathrm{n}^{\circ}$ & & $\mathrm{W} 1$ & & $\mathrm{~L}$ & $\mathrm{~L}$ & $\mathrm{~L}$ \\
\hline c. $\mathrm{n}^{\mathrm{j}} \mathrm{x}_{2} \Lambda \mathrm{n}^{\circ}$ & $\mathrm{W} 1$ & & & $\mathrm{~L}$ & $\mathrm{~L}$ & $\mathrm{~L}$ \\
\hline d. $\mathrm{n}^{\mathrm{j}} \mathrm{ek}_{1} \mathrm{x}_{2} \Lambda \mathrm{n}^{\circ}$ & & & $\mathrm{W} 1$ & $\mathrm{~L}$ & 1 & $\mathrm{~L}$ \\
\hline
\end{tabular}

The pre-consonantal glottal stop in (18) cannot be preserved due to a high ranking of *? (18)b. The glottal also cannot be deleted because of segmental MAX (18)c. Finally, as the candidate (18)d shows, the glottal stop also cannot be avoided by spreading place from a following consonant, since $*$ SPREAD dominates UNIFORMITY. The winning candidate (18)a involves a coalescence mapping, where the glottal stop is avoided, but no deletion has applied.

The ranking *? >> UNIFORMITY only becomes active post-lexically, and it serves to limit the range of contexts where glottal stops may occur. Simply put, all environments where a surface glottal stop shows up are cases of impossible coalescence. Glottal stop surfaces only in front of sonorants and vowels or before a pause. ${ }^{1}$ The key observation here is that continuancy can be compromised in coalescence, in order to avoid surface laryngeals, whereas the feature [sonorant] cannot. This is illustrated in (19) with the analysis of a glottal + sonorant cluster where coalescence does not apply: $\left|\mathrm{m}^{\mathrm{j}} \mathrm{a} \mathrm{P}^{\circ}\right|^{\prime}$ your tent' surfaces as $\left[\mathrm{m}^{\mathrm{j}} \mathrm{a} \mathrm{P}^{\circ}\right]$.

(19) Post-lexical coalescence cannot merge a sonorant consonant with a non-sonorant

\begin{tabular}{|rr|c|c|c|c:c:c|}
\hline & $\mathrm{m}^{\mathrm{j}} \mathrm{a}_{1} 1_{2}{ }^{\circ}$ & ID(son) & *SPREAD & *? & ID(cont) & ID(cg) & UNIF \\
\hline a. $\mathrm{m}^{\mathrm{j}} \mathrm{a}_{1} 1_{2}{ }^{\circ}$ & & & 1 & & & \\
\hline b. $\mathrm{m}^{\mathrm{j}} \mathrm{al}_{1,2}{ }^{\circ}$ & $\mathrm{W} 1$ & & $\mathrm{~L}$ & $\mathrm{~W} 1$ & $\mathrm{~W} 1$ & $\mathrm{~W} 1$ \\
\hline c. $\mathrm{m}^{\mathrm{j}} \mathrm{at}_{1} \mathrm{l}_{2}{ }^{\circ}$ & & $\mathrm{W} 1$ & $\mathrm{~L}$ & & & \\
\hline
\end{tabular}

If a sequence like $|21|$ were to undergo coalescence, as in (19)b, the result would inevitably violate IDENT(sonorant) since the two input consonants cannot simultaneously match the output. Ranking IDENT(sonorant) over *? rules out coalescence in these cases. (19)c demonstrates that the glottal stop cannot be avoided via place spreading due to a relatively high ranking of *SPREAD.

When placeless nasals are followed by another consonant at the post-lexical level, they restore their place via assimilation. In addition, the nasal + consonant combinations undergo a number of processes that we loosely dub NC effects. These processes are summarized in (20), with examples repeated from (6).

(20) The fate of placeless nasal: a summary

\begin{tabular}{|c|c|c|}
\hline Context & Process & Example \\
\hline $\mathrm{N}+/ \mathrm{mm}^{\mathrm{j}} \mathrm{n} \mathrm{n}^{\mathrm{j}} \mathrm{n} 1 \mathrm{l}^{\mathrm{j}} \mathrm{w} /$ & coalescence & $\mid$ weNl ${ }^{\circ} \mid\left[\right.$ wel $\left.^{\circ}\right]$ 'your dog' \\
\hline $\mathrm{N}+/ \mathrm{p} \mathrm{p}^{\mathrm{j}} \mathrm{t} \mathrm{t}^{\mathrm{j}} \mathrm{s} \mathrm{s} \mathrm{s}^{\mathrm{j}} /$ & voicing & $\begin{array}{l}\left|\mathrm{s}^{\mathrm{j}} \mathrm{i} \mathrm{Nta}\right|\left[\mathrm{s}^{\mathrm{j}} \mathrm{i}^{\mathrm{n} n \mathrm{na}}\right] \text { 'his lid' } \\
\left|\mathrm{peNs}^{\mathrm{jo}}\right|\left[\text { penz }^{\mathrm{j}}\right] \text { 'to put' }\end{array}$ \\
\hline $\mathrm{N}+/ \mathrm{x} /$ & $\begin{array}{l}\text { strengthening, } \\
\text { voicing }\end{array}$ & $\begin{array}{l}\left|\mathrm{s}^{\mathrm{j}} \mathrm{al} \Lambda \mathrm{Nx} \Lambda \mathrm{Nta}\right|\left[\mathrm{s}^{\mathrm{j}} \mathrm{al}^{\circ} \mathrm{\eta g} \Lambda \mathrm{nda}\right] \\
\text { 'underarm-POSS.3SG.DAT' }\end{array}$ \\
\hline
\end{tabular}

We assume that homorganic nasal + obstruent clusters in TN form complex segments (Clements 1987; Steriade 1993; Clements and Hume 1995; Halpert 2012; Shih and Inkelas 2014). We will thus write these sequences as monosegmental, e.g. $\left[{ }^{n} \mathrm{~d}\right]$, although this representation does not imply a change in our evaluation of the actual phonetic substance. We adopt the feature-based model of nasal contour segments spelled out in Clements (1987) and Clements and Hume (1995), although other approaches to contour segments would work as well (Steriade 1993; Halpert 2012; Shih and Inkelas 2014). In all of these models, a single unit at some level (the level of timing, or $X$-slots for Clements and Hume) dominates multiple units at a lower level (root nodes of Clements and Hume). For instance, the segment $\left[{ }^{n} \mathrm{~d}\right]$ involves one X-slot dominating two root nodes which differ in the features [nasal] and [sonorant]. Input-output correspondence

\footnotetext{
${ }^{1}$ The glottal in TN may occur after vowels or after the non-glottalizing consonants $/ \mathrm{b} 1 \mathrm{~m} \mathrm{r} /$. Although we do not attempt a full analysis of the alternations of these consonants, it can be assumed that no coalescence is possible here for the sake of the same constraint, which makes it impossible for these consonants to debuccalize in the first place.
} 
is defined on the higher of these levels, the level of X-slots (cf. Shih and Inkelas 2014 on correspondence between subsegmental nodes). A coalescence mapping like $\left|\mathrm{P}_{1} \mathrm{~s}_{2}\right| \rightarrow\left[\mathrm{ts}_{1,2}\right]$ thus amounts to merging two input X-slots into a single complex X-slot in the output. We further assume that the IDENT constraints are evaluated on X-Slots, and that a complex segment has all features of its parts for the purposes of inputoutput identity. Thus a prenasal affricate $\left[{ }^{n} \mathrm{~d}\right]$ is both $[+$ nasal $]$ and $[-$ nasal $]$ for the relevant purposes.

In nasal+consonant sequences, coalescence does not happen word-finally after a vowel. In this context, the placeless nasal turns into a glottal stop, as in (21). We assume that the nasal cannot surface due to a high ranking of $* \mathrm{~N}(21) \mathrm{b}$. The nasal also cannot regain its place via insertion of some feature, since CODACOND has to be obeyed (21)c.

(21) Post-lexical denasalization at a phrase boundary

\begin{tabular}{|c|c|c|c|c|c|c|c|c|c|}
\hline $\left.\mathrm{s}^{\mathrm{j}} \mathrm{i}_{1}{ }_{1} \mathrm{~N}_{2}\right]$ & $* \mathrm{~N}$ & $\begin{array}{l}\text { CODA } \\
\text { COND }\end{array}$ & MAX & ID(cons) & $\mathrm{ID}(\mathrm{son})$ & *? & ID(nas) & $\mathrm{ID}(\mathrm{cg})$ & UNIF \\
\hline a. $\quad \mathrm{s}^{\mathrm{j}} \mathrm{i}_{1}{ }_{1} \mathrm{R}_{2}$ & & & & & 1 & 1 & 1 & 1 & \\
\hline b. $\left.\quad \mathrm{s}^{\mathrm{j}} \mathrm{i}_{1}{ }_{1} \mathrm{~N}_{2}\right]$ & W1 & & & & $\mathrm{L}$ & $\mathrm{L}$ & $\mathrm{L}$ & $\mathrm{L}$ & \\
\hline c. $\left.\quad \mathrm{s}^{\mathrm{j}} \mathrm{i}_{1}{ }_{1} \mathrm{n}_{2}\right]$ & & W1 & & & $\mathrm{L}$ & $\mathrm{L}$ & $\mathrm{L}$ & $\mathrm{L}$ & \\
\hline d. $\left.\quad \mathrm{s}^{\mathrm{j}} \mathrm{i}_{1}{ }_{1}\right]$ & & & W1 & & $\mathrm{L}$ & $\mathrm{L}$ & $\mathrm{L}$ & $\mathrm{L}$ & \\
\hline e. $\quad \mathrm{s}^{\mathrm{j}} \mathrm{i}_{1,2}{ }_{1,2}$ & & & & W1 & $\mathrm{L}$ & $\mathrm{L}$ & 1 & $\mathrm{~L}$ & W1 \\
\hline
\end{tabular}

The candidate (21)d deletes the final consonant altogether, incurring a fatal violation of MAX. The candidate (21)e employs coalescence of a vowel + nasal instead of deletion. Coalescence of a vowel and a consonant is never possible in TN, and we attribute this to the constraint IDENT(consonantal). Thus, phrasefinal laryngeals are allowed post-lexically. The ranking illustrated in (21) also predicts the preservation of the final glottal stops, which come from an obstruent, as in [ $\mathrm{m}^{\mathrm{j}} \mathrm{a}$ ? ] 'tent'.

Although coalescence of a vowel and a consonant is not allowed, two consonants can merge, provided that they share the value of the feature [sonorant]. In this vacuous coalescence, a nasal essentially dissolves within the next sonorant, as in $\left|\mathrm{weNl}^{\circ}\right|$ 'your dog' surfacing as [wel ${ }^{\circ}$ (6). This mapping is analyzed in (22).

(22) Post-lexical coalescence of a nasal + sonorant

\begin{tabular}{|c|c|c|c|c|c|c|c|c|}
\hline & $\mathrm{weN}_{1} \mathrm{l}_{2}^{\circ}$ & $* \mathrm{~N}$ & ID(son) & *SPREAD & ID(nas) & ID(lat) & *? & UNIF \\
\hline a. & $\mathrm{wel}_{1,2}{ }^{\circ}$ & & & & 1 & 1 & & 1 \\
\hline b. & $\mathrm{weN}_{1} \mathrm{l}_{2}{ }^{\circ}$ & W1 & & & $\mathrm{L}$ & $\mathrm{L}$ & & $\mathrm{L}$ \\
\hline c. & $\mathrm{we}_{1} \mathrm{l}_{2}{ }^{\circ}$ & & W1 & & 1 & $\mathrm{~L}$ & W1 & $\mathrm{L}$ \\
\hline d. & wen $_{1} 1_{2}^{\circ}$ & & & W1 & $\mathrm{L}$ & $\mathrm{L}$ & & $\mathrm{L}$ \\
\hline e. & $\mathrm{we}^{\mathrm{n}} \mathrm{d}_{1,2^{\circ}}$ & & W1 & & $\mathrm{L}$ & 1 & & 1 \\
\hline
\end{tabular}

The underlying nasal leaves no surface trace in this case, and on our analysis this follows from the fact that all candidates preserving nasality fail. The placeless nasal cannot stay intact (22)b or change to the glottal stop (22)c due to $* \mathrm{~N}$ and $*$ ? The placeless nasal also cannot assimilate via place spreading due to *SPREAD (22)d. Finally, the nasal also cannot produce a well-formed complex segment $\left[{ }^{\mathrm{n}} \mathrm{d}\right]$ since this would involve a change in the feature [sonorant]: both merging consonants are sonorants, whereas the resulting complex segment is partially [-sonorant].

When a placeless nasal merges with a following voiceless stop, the result is a complex segment [ $\left.{ }^{\mathrm{n}} \mathrm{d}\right]$, as in $\left|\mathrm{s}^{\mathrm{j}} \mathrm{i} \cdot \mathrm{Nta}\right|\left[\mathrm{s}_{\mathrm{i}}{ }^{\mathrm{n}} \mathrm{nda}\right.$ 'his lid'. The analysis of this mapping is presented in (23). The change in voicing is mandated by the high-ranked constrain *NT, whereas keeping both segments without forming a complex segment is prohibited (again) by *SPREAD. The tableaux in (23)-(25) omit other ranking arguments, which are identical to those in (22).

(23) Post-lexical coalescence with voicing

\begin{tabular}{|rr|c:c|c:c|}
\hline & $\mathrm{s}^{\mathrm{j}} \mathrm{i} \cdot \mathrm{N}_{1} \mathrm{t}_{2} \mathrm{a}$ & ${ }^{* N T}$ & *SPREAD & ID(voi) & UNIF \\
\hline a. & $\mathrm{s}^{\mathrm{j}} \mathrm{i}^{\mathrm{n}}{ }^{\mathrm{n}} \mathrm{d}_{1,2} \mathrm{a}$ & & & 1 & 1 \\
\hline b. $\quad \mathrm{s}^{\mathrm{j}} \mathrm{n}^{\mathrm{n}} \mathrm{t}_{1,2} \mathrm{a}$ & $\mathrm{W} 1$ & & $\mathrm{~L}$ & 1 \\
\hline c. $\quad \mathrm{s}^{\mathrm{j}} \mathrm{i} \mathrm{n}_{1} \mathrm{~d}_{2} \mathrm{a}$ & & $\mathrm{W} 1$ & $\mathrm{~L}$ & $\mathrm{~L}$ \\
\hline
\end{tabular}


Interestingly, the merger of $|\mathrm{N}+\mathrm{s}|$ does not produce the same result as the $|\mathrm{N}+\mathrm{t}|$ merger. The outcome with strident fricatives is voicing without strengthening, that is, a prenasal affricate that could be transcribed as $\left[{ }^{\mathrm{n}} \mathrm{z}\right]$ rather than $\left[{ }^{\mathrm{n}} \mathrm{d}\right]$. We propose that this follows from a requirement to preserve the input feature [strident]. (24) shows the analysis of the mapping $\left|\mathrm{peNs}^{\mathrm{j}}{ }^{\mathrm{o}}\right| \rightarrow\left[\mathrm{pe}^{\mathrm{n}} \mathrm{z}^{\mathrm{j}}\right]$.

(24) Post-lexical coalescence preserves stridency

\begin{tabular}{|rc|c|c|c:c|}
\hline & peN $_{1} \mathrm{~s}_{2}{ }^{\circ}$ & ID(strid) & $* N F$ & ID(voi) & UNIF \\
\hline a. & pe $^{\mathrm{n}_{2} \mathrm{z}_{1,2}{ }^{\circ}}$ & & 1 & 1 & 1 \\
\hline b. & pe $^{\mathrm{n} \mathrm{d}_{1,2}{ }^{\circ}}$ & $\mathrm{W} 1$ & $\mathrm{~L}$ & $\mathrm{~L}$ & 1 \\
\hline
\end{tabular}

Finally, we turn to a case where post-nasal continuants undergo both hardening and voicing, such as $\left|\mathrm{n}^{\mathrm{j}} \mathrm{eN}_{1} \mathrm{x}_{2} \Lambda \mathrm{n}^{\mathrm{o}}\right|$ 'a woman's sledge' surfacing as $\left[\mathrm{n}^{\mathrm{j}} \mathrm{e}^{\mathrm{p}} \mathrm{g}_{1,2} \Lambda \mathrm{n}^{\circ}\right]$ in connected speech. The analysis of this mapping is given in (25), where we abstract away from the rankings required to guarantee coalescence, since these were already established in (22)-(23). Note that the winning candidate satisfies both IDENT(nasal) and IDENT(sonorant) since it preserves input specifications of both $/ \mathrm{N} /$ and $/ \mathrm{x} /$ on two distinct positions under the same X-Slot.

(25) Post-lexical coalescence with hardening and voicing

\begin{tabular}{|c|c|c|c|c|c|c|}
\hline & $\mathrm{n}^{\mathrm{j}} \mathrm{eN}_{1} \mathrm{x}_{2} \Lambda \mathrm{n}^{\circ}$ & $* \mathrm{NF}$ & *NT & ID(cont) & ID(voi) & UNIF \\
\hline$a$ & $\mathrm{n}^{\mathrm{j}} \mathrm{e}^{\mathrm{y}} \mathrm{g}_{1,2} \Lambda \mathrm{n}^{\circ}$ & & & 1 & 1 & 1 \\
\hline $\mathrm{b}$ & $n^{j} e^{\mathrm{p}} \gamma_{1,2} \Lambda n^{\circ}$ & $\mathrm{W} 1$ & & $\mathrm{~L}$ & 1 & 1 \\
\hline $\mathrm{c}$ & $\mathrm{n}^{\mathrm{j}} \mathrm{e}^{\mathrm{y}} \mathrm{k}_{1,2 \Lambda} \Lambda \mathrm{n}^{\circ}$ & & W1 & 1 & $\mathrm{~L}$ & 1 \\
\hline
\end{tabular}

The last part of the complex picture of TN consonant sandhi concerns the laryngeal features of obstruents, e.g., $/ \mathrm{t} /$ is voiced after vowels, but only if it was not preceded by a consonant underlyingly (cf. /ja-ta/ 'his earth' [jada] vs. / $\mathrm{m}^{\mathrm{j}} \mathrm{at}-\mathrm{ta} /$ 'his tent' is [ $\left.\mathrm{m}^{\mathrm{j}} \mathrm{ata}\right]$ and not $\left.{ }^{*}\left[\mathrm{~m}^{\mathrm{j}} \mathrm{ada}\right]\right)$. These alternations present a challenge for parallel OT since there is no surface-apparent reason for why /t/ would not voice in 'his tent'. Furthermore, the problem cannot be addressed by assigning postvocalic voicing to the lexical level, since the process operates across word boundaries.

We propose to treat the lack of voicing after underlying consonants as a gang effect. Under our coalescence analysis, the output of lexical level $\left|\mathrm{P}_{1}+\mathrm{t}_{2}\right|$ maps to $\left[\mathrm{t}_{1,2}\right]$ post-lexically. If the two consonants $\left|\mathrm{P}_{1}+\mathrm{t}_{2}\right|$ were to change to a surface [d, $\left.\mathrm{d}_{1,2}\right]$, this would involve a change not only in [voice], but also in [constricted glottis]. The reason for the lack of voicing in $\left|\mathrm{P}_{1}+\mathrm{t}_{2}\right|$ sequences is that both of these features cannot be changed at the same time. We formalize this intuition using a conjoined constraint IDENT(voice)\&IDENT(constricted glottis). This constraint is violated if a single output segment changes both laryngeal features of an input segment.

The tableau (26) shows our analysis of postvocalic voicing, which results from the ranking *VT $>>$ IDENT(voice).

(26) Post-vocalic voicing

\begin{tabular}{|rr|c|c|}
\hline & jata & *VT & ID(voi) \\
\hline a. & jada & & 1 \\
\hline b. & jata & W1 & \\
\hline
\end{tabular}

In (27), we show that a surface postvocalic [t] may escape voicing, if it corresponds to a segment in lexical level output, which had a [constricted glottis] specification. Thus the output of lexical level $\mid \mathrm{m}^{\mathrm{j}} \mathrm{a}$ ?ta| 'his house' maps to $\left[\mathrm{m}^{\mathrm{j}} \mathrm{ata}\right]$ rather than $*\left[\mathrm{~m}^{\mathrm{j}}\right.$ ada] post-lexically.

(27) No post-vocalic voicing for underlying consonant sequences

\begin{tabular}{|rc|c:c|c|c:c:c|}
\hline & $\mathrm{m}^{\mathrm{j}} \mathrm{a}_{1} \mathrm{t}_{2} \mathrm{a}$ & $\mathrm{ID}($ voi)\&ID(cg) & $* ?$ & $* \mathrm{VT}$ & $\mathrm{ID}($ voi) & $\mathrm{ID}(\mathrm{cg})$ & $\mathrm{UNIF}$ \\
\hline a. & $\mathrm{m}^{\mathrm{j}} \mathrm{at}_{1,2 \mathrm{a}}$ & & & 1 & & 1 & 1 \\
\hline b. & $\mathrm{m}^{\mathrm{j}} \mathrm{ad}_{1,2} \mathrm{a}$ & $\mathrm{W} 1$ & & $\mathrm{~L}$ & $\mathrm{~W} 1$ & 1 & $\mathrm{~L}$ \\
\hline c. & $\mathrm{m}^{\mathrm{j}} \mathrm{a}_{1} \mathrm{t}_{2} \mathrm{a}$ & & $\mathrm{W} 1$ & $\mathrm{~L}$ & & $\mathrm{~L}$ & $\mathrm{~L}$ \\
\hline
\end{tabular}


The winning candidate merges the two consonants, resulting in a violation of UNIFORMITY and IDENT(cg). The candidate $(27) \mathrm{b}$ shows intervocalic voicing, but it violates both IDENT(voice) and IDENT(cg), and thereby incurs a violation of a high-ranked conjoined constraint. Finally, the winning candidate violates *VT, but this violation cannot inhibit cluster simplification, since *? dominates *VT (27)c.

\section{Conclusions}

The proposed analysis of TN consonantal sandhi is coached in Stratal OT and crucially relies on an intermediate derivational step (lexical level) where all coda obstruents are glottal stops in TN and nasals are underspecified for place. Although the TN data show the need for cumulative constraint interaction (or gang effect), we think it may be premature to claim that all such effects should be allowed. In TN, it is the related featural changes that gang up, not some random changes. An intuitive observation that gang effects are limited to sets of related processes has also been made in other accounts of cumulative interactions (Itô and Mester 2003; Pater 2009).

\section{References}

Bermúdez-Otero, Ricardo. forthc. Stratal Optimality Theory. Oxford: OUP.

Bermúdez-Otero, Ricardo. 2011. Cyclicity. In Marc Van Oostendorp, Elizabeth Hume \& Keren Rice (eds.), The Blackwell Companion to Phonology, vol. 4, 2019-2048. Malden, MA: Blackwell.

Bermúdez-Otero, Ricardo. 2014. Stratal Phonology: arguments for cyclic containment, morphological implications. Ms, University of Manchester.

Bessell, Nicola. 1993. Towards a phonetic and phonological typology of post-velar articulation. PhD dissertation, University of British Columbia.

Bessell, Nicola \& Ewa Czaykowska-Higgins. 1992. Interior Salish evidence for placeless laryngeals. NELS 22 Proceedings, 35-49. Amherst, Mass: GLSA.

Clements, George N. 1987. Phonological feature representation and the description of intrusive stops. Parasession on autosegmental and metrical phonology. Chicago: Chicago Linguistic Society.

Clements, George N. \& Elizabeth Hume. 1995. The internal organization of speech sounds. In John Goldsmith (ed.), Handbook of Phonological Theory. Oxford: Blackwell.

Davis, Stuart \& Seung-Hoon Shin. 1999. The Syllable Contact Constraint in Korean: An OptimalityTheoretic Analysis. Journal of East Asian Linguistics 8(4). 285-312.

Gouskova, Maria, Elizabeth Zsiga \& One Tlale Boyer. 2011. Grounded constraints and the consonants of Setswana. Lingua 121(15). 2120-2152.

Halpert, Claire. 2012. Overlap-driven consequences of nasal place assimilation. In Philip Hoole, Lasse Bombien, Marianne Poulpier, Christine Mooshammer \& Barbara Kühnert (eds.), Consonant clusters and structural complexity, 345-368. Berlin, New York: De Gruyter.

Herbert, Robert K. 1986. Language Universals, Markedness Theory, and Natural Phonetic Processes. Walter de Gruyter.

Itô, Junko. 1986. Syllable theory in prosodic phonology. PhD dissertation, Umass Amherst.

Itô, Junko. 1989. A prosodic theory of epenthesis. NLLT 7(2). 217-259.

Itô, Junko \& Armin Mester. 2003. On the sources of opacity in OT: coda processes in German. In Caroline Féry \& Ruben van de Vijver (eds.), The Syllable in Optimality Theory, 271-303. Cambridge: CUP.

Itô, Junko, Armin Mester \& Jaye Padgett. 1995. Licensing and Underspecification in Optimality Theory. Linguistic Inquiry 26(4). 571-613.

Janhunen, Juha. 1984. Problems of Nenets phonology. In Péter Hajdú \& László Honti (eds.), Studien zur phonologischen Beschreibung uralischer Sprachen, 19-28. (Bibliotheca Uralica 7). Budapest: Akadémiai Kiadó.

Janhunen, Juha. 1986. Glottal stop in Nenets. (Mémoires de La Société Finno-Ougrienne 196). Helsinki.

Janhunen, Juha. 1993. Options for Tundra Nenets vowel analysis. In Marianne Bakró-Nagy \& Enikő Szíj (eds.), Hajdú Péter 70 Éves, 143-147. Budapest: Nyelvtudományi Intézet.

Kavitskaya, Darya \& Peter Staroverov. 2010. When an interaction is both opaque and transparent: the paradox of fed counterfeeding. Phonology 27. 255-288. 
Kiparsky, Paul. forthc. Paradigm Effects and Opacity. Stanford: CSLI Publications.

Kiparsky, Paul. 1982. Lexical Phonology and Morphology. In Yang In-Seok (ed.), Linguistics in the Morning Calm. Seoul.

Kiparsky, Paul. 1985. Some consequences of Lexical Phonology. Phonology Yearbook 2. 85-138.

Kiparsky, Paul. 2000. Opacity and cyclicity. The Linguistic Review 17(2-4). 351-366.

Kirchner, Robert. 1993. Turkish vowel harmony and disharmony: an Optimality Theoretic account. Ms, University of Alberta. ROA-4.

Lacy, Paul de. 2006. Markedness: Reduction and Preservation in Phonology. Cambridge: CUP.

Lombardi, Linda. 2001. Why place and voice are different: constraint interactions and feature faithfulness in Optimality Theory. In L. Lombardi (ed.), Segmental phonology in Optimality Theory: constraints and representations, 13-45. Cambridge: CUP.

Lombardi, Linda. 2002. Coronal epenthesis and markedness. Phonology 19(2). 219-251.

McCarthy, John J. 1994. The phonetics and phonology of Semitic pharyngeals. In Patricia Keating (ed.), Papers in Laboratory Phonology III: Phonological Structure and Phonetic Form, 191-233. Cambridge: CUP.

McCarthy, John J. 2008. The gradual path to cluster simplification. Phonology 25(2). 271-319.

McCarthy, John J. \& Alan Prince. 1993. Prosodic morphology: constraint interaction and satisfaction. Ms, UMass Amherst and Rutgers University.

McCarthy, John J. \& Alan Prince. 1995. Faithfulness and Reduplicative Identity. Ms, UMass Amherst and Rutgers University.

McCarthy, John J. \& Alan Prince. 1999. Faithfulness and identity in Prosodic Morphology. In René Kager, Harry van der Hulst \& Wim Zonneveld (eds.), Prosody-morphology interface. Cambridge: CUP.

Mohanan, Karuvannur. 1986. The Theory of Lexical Phonology. Dordrecht: Reidel.

Nikolaeva, Irina. 2014. A Grammar of Tundra Nenets. Berlin, Boston: De Gruyter Mouton.

Padgett, Jaye. 1994. Stricture and nasal place assimilation. Natural Language \& Linguistic Theory 12(3). 465-513.

Pater, Joe. 1996. *NC. In Jill Beckman (ed.), Proceedings of NELS 26, 227-239. Amherst, Mass: GLSA.

Pater, Joe. 1999. Austronesian Nasal Substitution and Other NC Effects. In René Kager, Harry van der Hulst \& Wim Zonneveld (eds.), The Prosody Morphology Interface, 310-343. Cambridge: CUP.

Pater, Joe. 2009. Weighted Constraints in Generative Linguistics. Cognitive Science 33(6). 999-1035.

Ramsammy, Michael. 2012. The realisation of coda nasals in Spanish. PhD Dissertation, University of Manchester.

Rose, Sharon. 1996. Variable laryngeals and vowel lowering. Phonology 13(01). 73-117.

Rubach, Jerzy. 2000. Glide and Glottal Stop Insertion in Slavic Languages: A DOT Analysis. Linguistic Inquiry 31(2). 271-317.

Salminen, Tapani. 1997. Tundra Nenets inflection. (Mémoires de La Société Finno-Ougrienne 227). Helsinki.

Salminen, Tapani. 1998a. Nenets. In Daniel Abondolo (ed.), The Uralic languages, 516-547. London: Routledge.

Salminen, Tapani. 1998b. A Morphological Dictionary of Tundra Nenets. Helsinki: Finno-Ugric Society.

Salminen, Tapani. 2012. Tundra Nenets grammatical sketch. Ms, University of Helsinki. http://www.helsinki.fi/ tasalmin/sketch.html.

Shih, Stephanie \& Sharon Inkelas. 2014. A subsegmental correspondence approach to contour tone (dis)harmony patterns. Proceedings of Phonology 2013. LSA.

Smolensky, Paul. 1993. Harmony, markedness, and phonological activity. Ms, Johns Hopkins University. ROA-87.

Staroverov, Peter. 2014. Splitting theory and consonant epenthesis. PhD dissertation, Rutgers University.

Steriade, Donca. 1993. Closure, release, and nasal contours. In Rena A. Krakow \& Marie K. Huffman (eds.), Nasals, Nasalization, and the Velum. (Phonetics and Phonology). New York: Academic Press.

Tereshchenko, Natal'ya M. 1956. Materialy i issledovaniya po yazyku nentsev. Moskva \& Leningrad: Izdatel'stvo AN SSSR.

Tereshchenko, Natal'ya M. 1965. Nenetsko-Russkii Slovar'. Moskva: Sovetskaya Entsiklopediya.

Zoll, Cheryl. 1996. Parsing below the segment in a constraint based framework. PhD dissertation, UC Berkeley. 